\title{
THE ENGLISH SPEAKING COMPETENCY AND CHALLENGES FOR BIPA TEACHERS
}

\author{
${ }^{* 1}$ Fadjar Indra Kurniawan, ${ }^{\# 2}$ Iwan Jazadi \\ ${ }^{*}$ English Student, English Department, STKIP Paracendekia NW Sumbawa, Indonesia \\ ${ }^{\# 2}$ English Lecturer, English Department, STKIP Paracendekia NW Sumbawa, Indonesia \\ Corresponding Author Email: iwanjazadi@gmail.com
}

\begin{abstract}
A B S T RA C T S
This research aimed to determine: (1) How important English speaking ability is for BIPA teachers; (2) What English speaking macro skills should be prepared to be a BIPA teacher; (3) What obstacles BIPA teachers find in the teaching process and how they solve them. This research used the qualitative method. The participants of this research were two BIPA teachers from different offices, from West Nusa Tenggara Province Language Office and Mataram Lingua Franca Institute. This research mostly used interviews to support the data of this research, while observation and documentation were used as supporting sources. The results of this research indicate that: (1) English speaking ability on A1 grade or the first grade is important because English is a bridge to connect the students to Indonesian; (2) There are five macro skills of English speaking ability that should be mastered by BIPA teachers; (3) The obstacles that mostly appear on the teaching process are based on the purpose of the learners to study Indonesian and the characteristics of each student from different countries.
\end{abstract}

How to cite: Kurniawan, F., \& Jazadi, I. (2021). The English Speaking Competency and Challenges for BIPA Teachers. Jo-ELT (Journal of English Language Teaching) Fakultas Pendidikan Bahasa \& Seni Prodi Pendidikan Bahasa Inggris IKIP, 8(2), 172-180. doi:https://doi.org/10.33394/jo-elt.v8i2.4398

\section{INTRODUCTION}

Indonesia is an independent country because of its patriots and youths. On October the 28th, 1928, The First Youth Congress was held. This congress consisted of the ambassadors of youths from many places in Indonesia (Sumatra, Java, Kalimantan, Sulawesi, etc.) to plan Independent Indonesia by recommending Sumpah Pemuda. The third point of Sumpah Pemuda is "Kami Putra dan Putri Indonesia Menjunjung Bahasa Persatuan, Bahasa Indonesia" (Aditya, 2021). Indonesian has then been officially stipulated as the national language of Indonesia since August the 18th, 1945. Repelita (2018) states that the purpose of the birth of the Indonesian language during the youth oath is essential so that the Indonesian nation has a unifying tool in the form of language to unite those 250 million citizens who speak some 718 regional languages spreading from Sabang in the west to Merauke in the east, from Manado in the north to Rote Island in the south of the archipelagic nation (CNN Indonesia, 2020).

As a national language serving a unifying lingua franca, Indonesian is found to be much easier to learn for several reasons. It has no changes in the conjugated verbs based on time or tenses; it has relatively consistent spelling; there is no gender difference in the nouns; the subject does not cause verb changes; the nouns do not have a specific plural forms and only 
need to be repeated. Yet, it is considered difficult in one thing, namely on the rules of the affixation use. Therefore, English speaking foreigners has rated that Indonesian can be learnt by a total stranger in about 9 months being in Indonesia, much faster than learning Arabic, Chinese, Japanese or any other language that does not share similar linguistic and cultural features with English that requires the learner to spend about two years in the target language country to be able to master the language well (Sensei, 2017).

At present, Indonesian is an established language as it has a standard big dictionary (KBBI), a guidebook on terminologies, structures, and spelling, a five-year regular national congress to accommodate new development, and a national language maintenance and development body that caters for language policy making in a day-to-day basis. Being the official language of the fourth and populous nation in the world and in line with the increasing role of Indonesia in the international forum, Indonesian has become an important language in the world. For example, Indonesian is the third after Spanish used in wordpress posting, has become a second language in Vietnam, and is studied in 52 countries (Bahtiar, 2019; Gunawan, 2020). Several reasons for foreigners to study Indonesian are to prepare the young people and women to work in Indonesia, interest in studying international law through the study of language differences, love of Indonesian language and culture, preparation for studying, and the need for research programs to be conducted in Indonesia (Hardinata, Budiana, \& Dewi, 2019). Nugraheni (2015) suggests other reasons why foreigners learn Indonesian, including reasons for work where foreign workers entering Indonesia are required to take the Indonesian Language Proficiency Test (UKBI), diplomatic affairs, study affairs and short-term affairs such as tourism.

Teaching Indonesian to Foreign Speakers (BIPA) is an important part in Indonesian language planning (Hardinata et al., 2019). The BIPA program is a process of learning the Indonesian language specifically for individuals whose mother tongue is not Indonesian and from outside Indonesia where this program covers the design of the Indonesian government under the auspices of the Ministry of Education and Culture's Language Development Agency as regulated in Government Law No. 242009 Article 44 (Jannah \& Yanti, 2020). Teaching BIPA means teaching Indonesian to foreign speakers, therefore BIPA teachers must have good knowledge of the target language (Kemdikbud, 2012). Tiawati (2018) states that insight related to how to pronounce the sounds of the language to be taught is the first knowledge that a BIPA teacher must have where at the beginner level, the teacher must have the ability to explain how sounds in Indonesian are produced by speech.

In addition to having a mastery of Indonesian as the target language, a BIPA teacher should have an effective mastery of the foreign learners' language (L1) especially when he/she teaches the beginning level students. Teachers and learners use learners' first language in a second or foreign language class to be able to ask and provide efficient clarifications and explanation of the lessons and as a means for develop social relationship (Pablo, Lengeling, Zenil, Crawford, \& Goodwin, 2011). Nation (2003) suggests that L1 is used at the beginning level because it is natural to communicate in L1 with students who share the same L1 background. The use of L1 is useful in preparing the students before they perform written or oral tasks in English. The L1 use reduces learners' shyness to engage with each other in learning the target language text. The L1 use can help ensure that the students are fully familiar with the topic to learn in the target language. Thus, using L1 can transfer learners' experiences to the target language and so learning process becomes effective (Madriñan, 2014). On the other hand, Pablo et al. (2011) found that, despite rampant use of L1, some students believe that L1 should not be used in a second or foreign language class. Both Pablo et al. (2011) and Nation (2003) highlight that L1 use should be reduced gradually as the learners' level increases. 
In BIPA teaching process, the teachers may face some obstacles. In terms of teaching BIPA in Indonesia, BIPA program participants tend to be adults who are critical although their natural sensitivity to learning a second language has somewhat decreased. On the other hand, some BIPA teachers do not have strong mastery of the participants' first and language and culture. With regard to BIPA teaching overseas, many students still perceive that learning Indonesian is not very important while the BIPA teachers do not have a special training and qualification before teachers; those who master Indonesian are assumed able to teach BIPA. Thus, many BIPA teachers overseas cannot increase the students' motivation to learn Indonesian (Hardini, Setyarini, \& Harto, 2021; Nugraheni, 2015).

This research focuses on BIPA teaching especially for beginning level participants who come from English speaking countries, especially on the BIPA teachers' speaking competency of English as the participants' L1. The research questions are how important English speaking competency is for BIPA teachers, what English speaking competencies should be mastered, and what challenges BIPA teachers face in teaching.

The findings of this research can be used as a basic hint or reference for the candidates of BIPA teachers, so they can prepare themselves in the future. The first purpose of this study is how important is English speaking ability. By knowing this point, the readers may know the level of English users that be the criteria of BIPA teachers based on the experiences and point of view of the informants.

The second point is the speaking macro skills that should be prepared as BIPA teachers. The purpose of this point is to know in detail about the English speaking skills based on what the informants experienced from the training and the skills being applied to their students overseas or in Indonesia.

The last is teaching obstacles based on the informants' experiences. This knowledge is to give the readers conception, idea, or depiction from the views that the informants shared in their explanations about the odds that they experienced during the teaching process.

\section{RESEARCH METHOD \\ Research Design}

This research was designed to be qualitative research. "Qualitative research is a type of social science research that collects and works with non-numerical data and that seeks to interpret meaning from these data that help understand social life through the study of targeted populations or places" (Crossman, 2020). "Qualitative research involves collecting and analyzing non-numerical data (e.g., text, video, or audio) to understand concepts, opinions, or experiences. It can be used to gather in-depth insights into a problem or generate new ideas for research. Qualitative research is commonly used in the humanities and social sciences, in subjects such as anthropology, sociology, education, health sciences, and history" (Bhandari, 2020).

\section{Subject}

The participants of this research were two qualified and certified BIPA teachers in West Nusa Tenggara Province Language Office and Mataram Lingua Franca Institute. These institutions require their BIPA teachers to have certificates and experiences in teaching Indonesian (KBNTB, 2021).

\section{Instruments}

In collecting the data, the researchers applied observation, interview, and documentation. In this method, the researchers used a notebook and handphone to collect the data from observation and interview. Documentation is material that provides official data or evidence that serves as a record" (Lexico, 2021). The specific data that the researchers 
collected in this research are the audio recording and notes about the explanation according to the questions asked, photos of them, and the teaching process.

\section{Data Analysis}

In analyzing the data of the English speaking ability of BIPA teachers, this research has done some steps to reduce, display, conclude and verify the data.

\section{RESEARCH FINDINGS AND DISCUSSION Research Findings}

The research findings come from two research informants (Mr. $\mathrm{Z}$ and Ms. H) as presented below.

\section{The Importance of English Speaking Competency in Teaching BIPA on A1 Grade}

The first informant, Mr. Z, explained that speaking ability was very important to become a BIPA teacher especially because the participants were mostly from English speaking countries such as Australia and the UK. He explained that the speaking ability of a good teacher could support a good teaching and learning process as well. At the beginning level (A1), students tended to use their own language (foreign language) to communicate during the learning process. Therefore, a teacher must have the ability to speak a good foreign language in order to teach the material, give instructions, and give assignments to students. However, English-speaking competency may not be a major consideration in the higher levels as the teacher may dominantly use Indonesian in teaching.

The second informant, Ms. H, explained that the importance of English depends on the teachers' placement or location of teaching. BIPA teachers can be placed in the country or abroad. BIPA teachers who are placed abroad consider mastering a foreign language (English) priority. This is because English is the language of instruction in the learning process. In addition, communication outside the classroom is related to academia, and communicating with people around to find information to support the teaching and learning process must use a foreign language (English). She further explained that BIPA teaching for beginning class (A1) might adopt two learning systems, namely using pure Indonesian in the entire learning process and using Indonesian only when giving simple instructions according to the conditions of the students. It aims to make students familiar with the target language. If it is a percentage, then the use of foreign language at level 1 is 70 percent and the use of Indonesian is 30 percent. Then at level 2, the use of foreign languages is 50 percent and the use of Indonesian is 50 percent. The higher the grade level, the higher the percentage of using Indonesian language in the learning process. In other words, English speaking competency is highly needed for being BIPA teachers for participants from English speaking countries.

\section{English Speaking Macro Skills BIPA Teachers of A1 Level Should Have}

The first informant, Mr. Z, explained that teachers must have good skills in listening, reading, writing, grammar, and speaking. However, the most important one is the ability to speak. This ability is very important because teaching Indonesian to foreign speakers requires good communication skills so that students can receive and understand all materials well. Thus, BIPA teachers must be at an intermediate or advanced English speaking level. In addition, BIPA teachers must also fulfill competencies in public speech, such as meaning negotiation, ability to explain the material, cultural understanding (both foreign and domestic cultures), pronunciation clarity, accuracy, fluency, intonation, and the ability to control the speed when speaking.

The second informant, Ms. H, explained that English speaking competency is very important, but both foreign and local BIPA teachers must have good writing skills and cross 
cultural knowledge. This is because the BIPA teachers have to translate written references from English into Indonesian according to the material taught. They also translate and prepare in writing Indonesian local materials into Indonesian and English because they not only teach how to speak good and correct Indonesian but also share the cultures of the archipelago. BIPA teachers who are Indonesian can teach their own culture to students, for example teaching Sasak culture if the BIPA teacher has a Sasak ethnic background. This is a form of pride in our own culture. It also shows the diversity of Indonesian culture in each province. Teaching material related to culture can be through various ways, for example through dance, stories, and poetry.

\section{Challenges in BIPA Teaching}

The first informant, Mr. Z, explained that the various characters of students with different national backgrounds are one of the challenges in teaching BIPA. The diversity in question is the way each student provides criticism of the material and the way the teacher teaches. Students who come from Australia are usually very critical so BIPA teachers must really prepare themselves by studying the culture of the students. In addition, most of the students are adults. Adults tend to be easily frustrated if the material provided is too much, even students sometimes ask the teacher to change the material according to what they need. Therefore, a BIPA teacher must really prepare to face all the challenges.

The second informant, Ms. H, explained that Even though BIPA teachers already have all the competencies needed to teach, they also face challenges in the teaching process. The duration of time given by the university to the foreign students is sometimes too short, especially if the BIPA material is used as an elective course. In addition, the different cultural backgrounds of each student are one of the obstacles in teaching BIPA. Thus, BIPA teachers must be able to focus on the main goal, namely teaching Indonesian. The cultural diversity of students can be used as a comparison between one culture and another so that the obstacle related to culture can be overcome.

\section{Discussion}

\section{The Importance of English Speaking Competency in Teaching BIPA on A1 Grade}

From the explanations of the informants of this research, English speaking competency is classified based on the grade. A1 grade is the beginner class for foreign people who want to start or to learn Indonesian. Beginners mean those who firstly learn things on purpose (here is to learn Indonesian) and the foreign people here are the English native speakers. As a beginner in learning Indonesian, a foreign speaker still lacks knowledge and vocabulary. The students need English and a teacher who speaks English well, so they can engage in the teaching and learning well. BIPA teachers must use English as the language of instruction to convey material and give instructions to students. Based on this, the researchers conclude that speaking ability is an important thing that must be possessed by BIPA teachers. This finding is in line with previous studies by Nation (2003), Pablo et al. (2011), and Madriñan (2014) that L1 use helps beginning level students to familiarize and prepare themselves cognitively with the foreign language materials and helps shy students to transform socially and psychologically into the target language situation.

\section{English Speaking Macro Skills BIPA Teachers of A1 Level Should Have}

Both informants agree that BIPA teachers of A1 level should have an intermediate to advanced mastery of English. The speaking macro skills of such level of English mastery are in line with descriptions given by (Brown, 2003, p. 172) as explained below. 


\section{a. Grammar}

A BIPA teacher should be able to cope with basic structures quite correctly but may not have comprehensive control of them. From the data that the researcher got, accuracy points, which are one of the competencies that BIPA teacher must possess, are closely related to the structure of speaking, including teaching Indonesian in A class. The grammar ability of BIPA teachers, both foreign and Indonesian, is very important. This is because BIPA teachers not only focus on how to pronounce Indonesian but also focus on how to make students understand and be able to use good and correct Indonesian according to Indonesian language rules. An example of a case where the mastery of grammar is needed by a BIPA teacher is when a BIPA teacher will translate material from English to Indonesian or vice versa.

\section{b. Fluency}

A BIPA teacher should be able to cope with most social conditions, such as introductions and non-formal conversations about actual issues and daily topics. Fluency is needed in the process of delivering material and answering student questions. Fluency means that BIPA teachers do not use pauses such as "aaa .." and mix languages in educational processes. In the first grade, English is the bridge for learners to understand the use of Indonesian. This argumentation is supported by one of the informants that explanation about the percentage of the use of English in level 1 or A1 grade by using English 70 percent.

\section{c. Task}

A BIPA teacher should be able to fulfill normal social and work demands and may ask for help in facing complex problems. Teaching language and culture are inseparable. BIPA teachers cannot teach language without cultural knowledge. BIPA teachers look for good communicative ability and should be interesting in the way they deliver the materials. If BIPA teachers introduce one topic, it is not only about one aspect of content, but it should combine with additional knowledge, just like Indonesian, involved with its culture. Being a BIPA teacher, it is an obligation to learn about culture too, not only language. In addition, a BIPA teacher should know how to create interest in teaching or maybe talk to strangers outside of the class. BIPA teachers have to prepare themselves to face a situation when students have difficulties in learning.

\section{d. Comprehension}

A BIPA teacher should be able to understand the main points of conversations of general subjects that do not require special terms). Students or learners in A1 class usually ask using their languages (foreign languages). If BIPA teachers cannot understand about what the students ask, how they cant teach the students. People who want to be BIPA teachers should prepare themselves and learn more English communication because it is specific to English. Thus, English comprehension is the key to success in teaching BIPA to foreign learners.

\section{e. Pronunciation}

A BIPA teacher has an accent that is intelligible though often quite faulty. On this point of assessment, a clarity is another important thing that BIPA teachers must have. Every teacher should be able to explain or talk in English clearly, because the teacher is the bridge for students to understand Indonesian. If BIPA teachers do not have the clarity, they cannot give any benefit. 


\section{Challenges in Teaching BIPA on A1 Grade}

On the students' side, inability or lack of knowledge in Indonesian is one of the major teacher obstacles during the teaching process. Other obstacles may appear during the teaching and learning process from the students. Teaching is not always about delivering or distributing knowledge from the teachers, but the teachers also have to make good frequent connections to get the students' attention. The learning culture seems different in each group of countries. This finding is in line with previous research by Richards (2011) who argues that teachers must have the ability to provide a good language model, to maintain the use of the target language in the classroom, to provide correct feedback on the learner's language, and to provide input at an appropriate level of difficulty.

The characters of learners are different from country to country. What is common, though, is that most of the students are critical. The students usually question the way teachers teach them. This can be an obstacle to be BIPA teachers. It means that the candidates of BIPA teachers should be ready materially and mentally. The thing that should be prepared is not always about the teaching material, but also about cultural differences and understanding. This finding is in line with previous research by Orlova (2014) and Tedjasuksmana (2013) that cultural elements should be integrated into foreign language teaching.

Duration when teaching BIPA is also an obstacle other than the various characters of students. The period specified by the foreign partner university may be too short, especially when BIPA materials are used as electives. In some cases, students sometimes ask for more time to study, however, the campus cannot provide additional time so that inevitably the class must end. This finding on non-teaching obstacle is similar to a previous study by Hardinata et al. (2019) that a BIPA teacher should be able to adjust herself/himself and her/his teaching plans with the school environment and situation in ways that minimize learners" failure.

Then, the students taught in the BIPA class are adults so they cannot be treated like teaching children. Students sometimes ask the teacher to change the material at a meeting according to their needs. However, giving too much material to students will make them easily frustrated. In this case, the teacher must be able to manage time and manage teaching styles that can make students excited to learn and eager to follow the next lesson or material. Thus, BIPA teachers should apply principles of andragogy (skills to teach adults) to their adult learners (El-Amin, 2020).

\section{CONCLUSION}

A1 grade of Bahasa Indonesia for foreign speakers (BIPA) is the basic or the beginner class for those who want to learn Indonesian from the beginning of it. However, this class may not only consist of kids but also teenagers and adults. The purpose of their studies are different based on their needs. The research shows that English ability is important for BIPA teachers, yet the most important ability that BIPA teachers should have speaking competency. Such speaking competency should meet intermediate to advanced level speaking macro-skills in terms of grammar, fluency, task, comprehension, and pronunciation.

Based on the challenges, BIPA teachers are suggested to prepare themselves to face many circumstances when they are at teaching sessions. In addition to the foreign language mastery, BIPA teachers should learn the students' cultural background and critical ability, equip themselves with the Indonesian or their own local or ethnic cultural knowledge, and be conversant with student-centered teaching and andragogy besides pedagogy or skills to teach children.It is also suggested that Indonesia Education Study Program at the university develop a strong concentration with substantial number of subjects including courses on the learners' L1 focusing on speaking macro-skills, cross-cultural understanding, and andragogy. 
Finally, it is acknowledged this research still relied on a small number of participants, future research on BIPA teachers' competency of the foreign learners' language, especially English, is highly needed as this area is still under-researched up to the present, whereas its impact for making effective BIPA teaching is awaited.

\section{REFERENCES}

Aditya, R. (2021, 10 May 2021). Isi Sumpah Pemuda, Naskah Pemersatu Bangsa Indonesia. suara.com. Retrieved from https://www.suara.com/news/2021/05/05/122439/isisumpah-pemuda-naskah-pemersatu-bangsa-indonesia?page=all

Bahtiar, A. (2019, 29 May). Bahasa Indonesia, (Menjadi) Bahasa Dunia. Republika. Retrieved from https://www.republika.co.id/berita/ps932m257/bahasa-indonesiamenjadi-bahasa-dunia

Bhandari, P. (2020). What is Qualitative Research Methods \& Examples. scribbr.com. Retrieved from https://www.scribbr.com/methodology/qualitative-research/

Brown, H. D. (2003). Language Assessment: Principles and Classroom Practices. California: Longman.

CNN Indonesia. (2020, 21 February 2020). Kemendikbud: 11 Bahasa Daerah Punah, 25 Terancam Menyusul. CNN Indonesia. Retrieved from https://www.cnnindonesia.com/nasional/20200221144218-20-476834/kemendikbud11-bahasa-daerah-punah-25-terancam-menyusul

Crossman, A. (2020). What Is Qualitative Research. Thoughtco. Retrieved from https://www.thoughtco.com/qualitative-research-methods-3026555

El-Amin, A. (2020). Andragogy: A Theory in Practice in Higher Education. Journal of Research in Higher Education, 4(2), 54-69.

Gunawan, H. I. (2020). Bahasa Indonesia Lingua Franca Pencetak Karakter Negeri (1st ed.). East Java: Pena Persada.

Hardinata, V., Budiana, N., \& Dewi, P. K. (2019). Pengembangan Buku Teks Bahasa Indonesia Untuk Penutur Asing Tingkat Pemula Berbasis Kearifan Lokal Wisata Malang. BEBASAN Jurnal Ilmiah Kebahasaan dan Kesastraan, 6(1), 25-41.

Hardini, T. I., Setyarini, S., \& Harto, S. (2021). Remote Learning Implemented By Bipa Teachers During Covid-19 Pandemic. Jurnal Kependidikan: Penelitian Inovasi Pembelajaran, 5(1).

Jannah, R., \& Yanti, P. G. (2020). Pembelajaran Bahasa Indonesia Bagi Penutur Asing Menggunakan Metode Darmawisata. Imajeri: Jurnal Pendidikan Bahasa dan Sastra Indonesia, 2(2), 182-189.

KBNTB. (2021). Bahasa Indonesia Bagi Penutur Asing. Kantor Bahasa NTB. Retrieved from http://kantorbahasantb.kemdikbud.go.id/index.php/pages/bipa

Kemdikbud. (2012). Bahasa Indonesia bagi Penutur Asing (BIPA) | Badan Pengembangan dan Pembinaan Bahasa, Kementerian Pendidikan dan Kebudayaan. Badan Bahasa. Retrieved November 19,
http://badanbahasa.kemdikbud.go.id/lamanbahasa/info_bipa.

2020

Lexico. (2021). Definition of Documentation. In lexico.com dictionary. Retrieved from https://www.lexico.com/definition/documentation

Madriñan, M. S. (2014). The Use of First Language in the Second-Language Classroom: A Support for Second Language Acquisition. Gist Education and Learning Research Journal, 9, 50-66.

Nation, P. (2003). The Role of the First Language in Foreign Language Learning. Asian EFL Journal, 5(2), 1-8. 
Nugraheni, A. S. (2015). Pengembangan Program Profesionalisme Dosen Pengajar Bahasa Indonesia untuk Penutur Asing (BIPA) di ASEAN. Al-Bidayah: Jurnal Pendidikan Dasar Islam, 7,(1).

Orlova, Y. (2014). Integration of Culture in Teaching a Foreign Language. (MA), California State University, Chico.

Pablo, I. M., Lengeling, M. M., Zenil, B. R., Crawford, T., \& Goodwin, D. (2011). Students and Teachers' Reasons for Using the First Language Within the Foreign Language Classroom (French and English) in Central Mexico. PROFILE, 13(2), 113-129.

Repelita, T. (2018). Sejarah Perkembangan Bahasa Indonesia (Ditinjau dari Perspektif Sejarah Bangsa Indonesia). Jurnal Artefak, 5(1), 45-48.

Richards, J. C. (2011). Exploring Teacher Competence in Language Teaching. JALT, 35(4), 3-7.

Sensei, Y. (2017, 13 September 2017). Bahasa Indonesia itu Gampang atau Susah, sih?. zenius.net. Retrieved from https://www.zenius.net/blog/belajar-bahasa-indonesia

Tedjasuksmana, H. J. H. (2013). Teaching Culture to Adult Indonesian Students in English Classrooms: A Mutual Understanding Approach. Magister Scientiae, 34, 194-202.

Tiawati, R. L. (2018). Indonesian Language Learning Planning For Foreigners (BIPA) For Beginners Level (Perencanaan Pembelajaran Bahasa Indonesia Bagi Penutur Asing (BIPA) Untuk Tingkat Pemula). Jurnal Gramatika, 4(2), 393-402. 